UDC 378.6

DOI: $10.31733 / 2078-3566-2019-5-292-297$

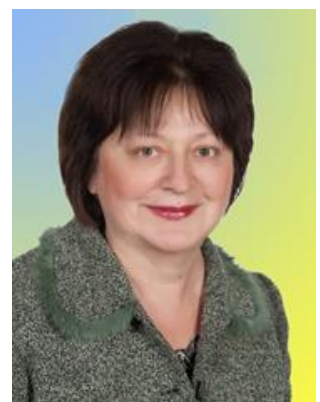

\section{Lidiya}

MARKINA ${ }^{\circledR}$

Ph.D, Ass. Prof.

(Dnipropetrovsk

State University

of Internal Affairs)

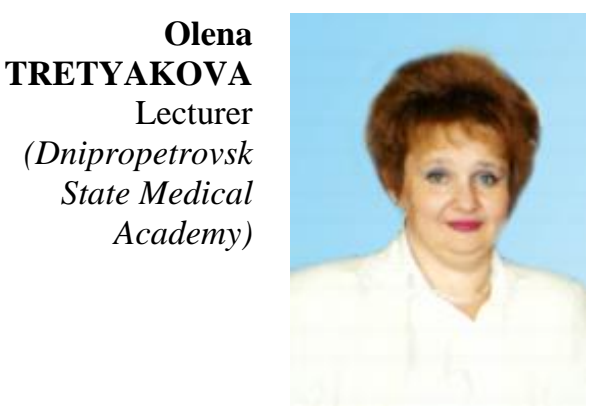

\title{
THE IMPLEMENTATION OF THE INTEGRATIVE APPROACH IN THE PROCESS OF TRAINING FUTURE LAW ENFORCEMENT OFFICERS IS THE URGENT REQUIREMENT OF MODERNITY
}

Лідія Маркіна, Олена Третьякова. РЕАЛІЗАЦІЯ ІНТЕГРАТИВНОГО ПІДХОДУ В ПРОЦЕСІ ПДГОТОВКИ МАЙБУТНІХ ПРАВООХОРОНЦІВ - НАГАЛЬНА ПОТРЕБА СУЧАСНОСТІ. Здійснено аналіз проблем і шляхів їх вирішення в процесі підготовки сучасних правоохоронців у сфері гуманітарних наук. Виявлено об'єктивні взаємозв'язки між навчальними дисциплінами; розуміння єдності визначеного кола знань, способів дії і пізнавальних підходів; формування системи знань, які потребують комплексного застосування у процесі правоохоронної діяльності. Охарактеризовано дидактичний ефект інтеграції психологічних та правових знань. Доведено, що у теперішній час спостерігається посилення тенденції інтеграції правових i лінгвістичних знань. Обгрунтовано, що цей процес зумовлений необхідністю створення досконалих законодавчих актів у країні; нагальністю правового регулювання проблем мовної політики; необхідністю уникнення різнотипного тлумачення нормативних актів; потребою вдосконалення сучасної правничої терміносистеми; системним застосуванням методів лінгвістики в ході криміналістичних експертиз; актуальністю вдосконалення метамови юридичної науки.

Розглянуто питання підвищення якості лінгвістичних знань правоохоронця у таких аспектах:1) соціолінгвістичний: мова, як суспільне явище; специфіка правової функції мови; літературна мова і соціальні діалекти; 2) прагматичний: особливості слововживання в юридичних текстах, поняття юридичного дискурсу; 3) термінологічний: загальне поняття терміна і терміносистеми; специфіка юридичної термінології; етимологія й семантика базових термінів; класифікації та стратифікації юридичних термінів сучасних іноземних мов; 4) стилістичний особливості наукового стилю у правовій сфері; 5) лексикографічний: можливості застосування словників різних типів у професійній діяльності правника; порівняльний аналіз дефініцій у юридичних енциклопедичних i лінгвістичних словниках; 6) герменевтичний: поняття лінгвістичного тлумачення текстів законодавчих i підзаконних актів; розмежування систематичного, історичного, цільового і лінгвістичного способу тлумачення змісту правової норми; 7) психолінгвістичний: співвідношення мовної та правової поведінки особи; істина й неправда в словесній картині світу; 8) криміналістичний: лінгвістичні вимоги до підготовки матеріалів на експертизу; можливості застосування мовних знань для ідентифікації особи за ії мовленням: деонтологічний: правова комунікативна деонтика юристів різних країн; 9) компаративний: лінгвістичні аспекти правової компаративістики; діахронна компаративістика правових текстів. Окреслено шляхи та подані рекомендації щодо розробки підходів інтеграції права и мови. Акцентовано увагу на змістовної інтеграції пізнавальної діяльності майбутніх правоохоронців, забезпечення комплексного підходу до мети та завдань професійного навчання, орієнтації на різнобічну глибоку професійну підготовку. Доведено, що систематична реалізація принципу інтеграції допомагає вирішити протиріччя між предметним навчанням і необхідністю системного використання міжпредметних знань в процесі правоохоронної діяльності.

Ключові слова: правоохоронна діяльність, лінгвістика, міждисциплінарні зв'язки, інтегрування, психологія, мовленнєва компетентність, освіченість.

\footnotetext{
(C) Markina L., 2019

ORCID iD: https://orcid.org/0000-0003-0119-9149

k_pp@dduvs.in.ua

(C) Tretyakova O., 2019

languages@dma.dp.ua
} 
Problem statement. The process of training modern law enforcement officers is carried out in conditions of intensive integration of scientific knowledge. Implementation of the integrative approach allows building educational and professional activities of future law enforcement officers on the systematic basis. Integration is the condition of didactic reflection in the individual consciousness of the applicant of higher education of objective interrelations between educational disciplines; understanding of unity of the certain circle of knowledge, ways of action and cognitive approaches; formation of system of knowledge which require complex application in the course of law enforcement activity.

Analysis of publications that started solving this problem. The problem of training and education of specialists of different specialties attracted great attention of researchers at different times and in different countries. Ancient philosophers and statesmen - Confucius, Cicero, Caesar wrote about the moral, moral and mental state of the "representative of the law". The French lawyers who drafted the "Napoleon Code" noted the need for comprehensive training of judges and prosecutors. (D'alembert) Modern Ukrainian researchers V. G. Kremen, V. M. Nagayev in their works suggest ways to modernize the current educational process, the integration of various disciplines in order to improve the educational level of specialists.

The article's objective is to find out the ways of integrity different disciplines during training of future law enforcement officers.

Basic content. More and more attention has been paid to the problem of integration of $\mathrm{Hu}-$ manities in recent years. This is explained, on the one hand, by returning to anthropological approaches in science. And on the other, understanding, it is the necessity of complex interdisciplinary research. It can be stated that today "legal statistics", "legal psychology", "philosophy of law" and others have achieved the certain status. They are rapidly developing scientific fields.

The pedagogical effect of integrative processes is that the pedagogical functions of the discipline are expanded; it is possible to streamline interaction with other academic disciplines in terms of ensuring the deeper assimilation of knowledge and skills, the formation of concepts. These concepts have the universal character; they are used in mastering the content of various disciplines.

Future law enforcement officers have the capability to use the clue concept of "psyche" in terms of the solution of multi-level teaching and professional tasks systematically. They may carry on it on the basis of correlation between educational disciplines "Psychology", "Social psychology," "Public psychology," "Legal conflictology", "Legal psychology" on the principle of coordination.

Studying of subjects "Effective communication", "Stress resistance", "Tolerance and non-discrimination in the work of patrol officers" is provided. These disciplines have direct links with psychological knowledge. They are put into practice during the selection of candidates for the new patrol police at the courses of primary professional training of employees of patrol service units, [5].Classes are held in the form of specialized trainings, business games using interactive methods, and they have the clear professional orientation.

In the process of integration of psychological and legal knowledge, interpenetration, consolidation, unification of knowledge are carried out, there is the gradual change of individual didactic elements, which are included in the large number of connections and relationships.

It ought to be emphasized that at present there is the growing trend of integration of legal and linguistic knowledge. This process is due to the number of reasons, namely:

- the need to create perfect legislation in the country. They should meet the requirements of many sciences, and first of all legal and linguistic, more effectively justify the legal norms; use linguistic knowledge in the process of law enforcement activity;

- urgency of legal regulation of language policy problems;

- the need to avoid different types of interpretation of legal regulations;

- the need to improve the modern legal term system;

-systematic application of linguistics methods in the course of forensic examinations, etc.;

- the relevance of improving the natural semantic language of legal science.

It should be noted that the problem of integrative relations of linguistics and law has not arisen recently. As the history of the state and law testifies, only at the stage of functioning of Customary Law there was no need for written reproduction and legislative consolidation of the legal norm. With the emergence of the state with the establishment of a fundamentally new type of legal relations, the need for textual law, although at the empirical level appeared.

Already before the drafters of the "Laws of Hammurabi"," Laws of the Twelve tables", "Russian truth" the question of the choice of language means, the creation of the first legal cli- 
chés arose. It was necessary of such sign forms which were understandable to all native speakers, i.e. the primary foundations of legal hermeneutics are created which were on the verge of jurisprudence, linguistics and logic.

So it can be taken into account that the movement from casuistry to legal norms, from the historical stages of legal ignorance to the level of pre-law and to the level of understanding the need for written-fixed legal norms was accompanied by certain developments in the linguistic and legal sphere. Already at this stage of development of mankind it became obvious that without language the right could not exist, after all the speech materialized will of the ruler, fixed legal relations in all spheres of human life. Among all known sign systems, language is the main means of information transmission, communication and nomination and reference of objects, phenomena and events.

Thus, the creation of legislative acts is not possible without knowledge of linguistics, basic rules of legislative style, and means of transmission of legally significant information, arguments, and rules of judicial debate.

M.V. Lomonosov aptly said about the need to integrate linguistics and law: "Dubious Jurisprudence without grammar"[4, p. 443]. Regardless, a lot of questions in this perspective about the language competence of lawyers are present.

Without any doubt, there is no need for law enforcement officers to have the level of linguistic knowledge which is provided for philologists, but it is advisable today to talk about knowledge of such aspects as:

1) social linguistics: language as the social phenomenon; specificity of the legal function of language; literary language and social dialects; 2) pragmatic: features of word usage in legal texts, the concept of legal discourse; 3) terminological: the general concept of the term and terminological system; specificity of legal terminology; etymology and semantics of basic terms; classification and stratification of legal terms of modern foreign languages; 4) stylistic: features of scientific style in the legal sphere;

5) lexicographic: possibilities of application of dictionaries of various types in professional the lawyer's activity; the comparative analysis of definitions in legal encyclopedic and linguistic dictionaries; 6) hermeneutics: the concept of linguistic interpretation of texts of legislative and bylaws; differentiation of systematic, historical, purposeful and linguistic ways of interpretation of legal norms; 7) psycholinguistic: correlation of linguistic and legal behavior of the person; truth and untruth in the verbal picture of the world; 8) criminalistic: linguistic requirements for the preparation of materials for examination; the possibility of using language knowledge to identify the person by her/his speech: deontological: legal communicative deontics of lawyers in different countries; 9) comparative: linguistic aspects of legal comparativistics; diachronic comparativistics of legal texts.

At first point of view, this is too complicated approach, but even Ferdinand de Saussure drew attention to the unequal possibilities of different languages. Some of them can express what others are unable to express ""... there are some languages for which the expression "sitting in the sun" is impossible." He pointed out the inferiority of one language or another, no, to its otherness. That is why it is believed that working in the legal field requires consideration of all the above aspects in order to achieve the main goal of their professional activities.

The question of the law enforcement officer's development of speech culture deserves special attention today. Language is the highest cultural value of society. These values are "the integration basis for any small or large social group, culture, nation, humanity as a whole." $[2$, c. $3-5]$.

The level of speech development has always been considered as the level of development of human intelligence and morality, so the definition of ways of mastering it at a high professional level, the development of a means of improving is the urgent problem of pedagogical, linguistic and legal sciences.

The profession of the policeman requires awareness, primarily with legal and military terminology, and also requires knowledge on branch business documentation. However, first of all, it is necessary to master the state language.

The state language is usually called the main language of the state recognized by the Constitution or the law, which satisfies the needs of society in official communication and acts as one of the symbols of state national and cultural sovereignty.

The official language in the scientific literature is understood as the government language recognized by the law, obligatory for legislative and state executive authorities, judicial proceedings, education. 
Article 10 of the current Constitution of Ukraine states " " the State language in Ukraine is the Ukrainian language" It means that the Ukrainian language is the language of acts of public authorities and management, the language of record-keeping and documentation, the language of legal proceedings, administrative proceedings. Notarial record-keeping, prosecutorial supervision, language of international treaties and agreements, education, language of mass media (television, radio, press), language of communication (post, telephone), language of official names of state and public bodies, economic bodies, economic societies, etc.

The hypothesis of linguistic relativity of Sepir - Whorf is known that language is not just the means of expression and design of thoughts - it determines the course of our thoughts. As a result, cultures that differ in languages are formed and other ideas about the world. Therefore, the Chinese not only speaks, but also thinks differently than the Frenchman, an Englishman or the Arab or the Ukrainian.

Today it is known that the significant part of legal terms has Latin origin (lawyer, arrest, decree, militia, recidivism), because the foundations of jurisprudence belonged to Ancient Rome. Many words from Greek (amnesty, dactylograma, drugs, paradox, police). Directly from French the next words are (arbitrator, bureaucrat, dossier, passport), from English (business, kidnapping, killer, lobby, hacker), from German - (accounting, bill), from Italian - (gang, fiasco), from Polynesian taboo, from - Arabic-hashish. Many words entered through indirectly through the third languagevacancy, version, visa, directive, and impeachment. Only knowledge of foreign languages can find the suitable term or expression, because often the same words change their meaning to unknowability, and even worse they have variability

It is known that the definition of administrative misconduct was the result of scientific research and efforts of several generations of lawyers and linguists. The term administrative offense (delict) comes from the Latin "delictum" - the misdemeanor, the crime and manifests itself in an act or omission that is contrary to the law.

The relevance of the definition lies in the fact that the interpretation of the concept of «administrative delict" depends on the decisive importance of such specific issues of administrative law, as the grounds of administrative responsibility, qualification, application of administrative penalties and their commission. It means that the choice of legal and special measures for the prevention of administrative offenses and improving the efficiency of administrative legislation depends on what meaning will be invested in this concept.

On the basis of these facts, it can be argued that today the typology of terms and terminological constructions become the more acute problem for scholars of law and linguistics. It will facilitate the translation process, help to avoid possible errors in the selection of Ukrainian correspondences and create conditions for the further development and improvement of modern legal speech.

Thus, the development of ways to integrate law and language, the creation of the separate applied science and discipline, the definition of their common foundations is not the fashion, but an urgent need of society.

So, thanks to meaningful integration cognitive activity of future law enforcement officers goes beyond the curriculum of the discipline; provides the comprehensive approach to the goals and objectives of vocational training, orientation to the comprehensive deep professional training. Systematic implementation of the principle of integration helps to solve the contradiction between subject training and the need for systematic use of interdisciplinary knowledge in the process of law enforcement.

The principle of integration is implemented in order to use the conclusions (rules, principles) of one science to explain the conclusions (or facts) of another science (discipline), allows the future law enforcement officer to develop the ability to integrate the knowledge and use it in practice, to ensure greater intensity, independence of cognitive activity.

It should be noted that the principle of integration is correlated with the general didactic principles of scientific, systematic and consistent, consciousness and activity, the connection of theory with practice, learning motivation, and professional orientation. Proceeding from features of credit system of training, it is expedient to adhere to the following principles: structuring of training, optimality of methods of activity, flexibility, the realized prospect [6, p. 128, 129]. It is advisable to use the principle of integration when all other principles are taken into account at the same time.

Due to the consolidation of didactic units of educational material, the implementation of the integrative approach helps to avoid mental overload, psychophysiological stress of applicants for higher education. As V. G. Kremen says, " for personality-oriented learning it is not 
indifferent what psychological price the student pays for his mental assets. It is clear, that training cannot be considered optimal which creates the situation of psychological discomfort for the student " [3, p. 64].

The educational function of integration processes is reflected in the formation of the positive evaluation attitude to future law enforcement activities.

The developing function of integration is to create additional reserves for the development of the creative personality of the policeman. The involvement of applicants for higher education in the process of mastering the educational material on the basis of the integrative approach is carried out with the help of certain means:

- complex problem questions (the fact that the answers to them require applicants for higher education to actively attract knowledge from different disciplines, as well as other sources);

- complex inductive cognitive tasks when facts from different academic disciplines are generalized;

- complex partially-inductive cognitive tasks, when there is the interdisciplinary generalization of already generalized subject knowledge (concepts, theories, laws);

- complex deductive cognitive tasks that require evidence of general scientific provisions through the integration of knowledge from different subjects;

- the solution of professional situations of various contents (in contrast to the complex cognitive problem, the problem of which is derived from the content of educational subjects, the professional situation is set as a very real event);

- practical situations for socio-psychological training (for example, for the acquisition of law enforcement experience of business relationships characteristic of law enforcement, the formation of communicative culture);

- exercises for working off the certain complex of rather complicated professional actions of law enforcement officers.

Conclusions. It is necessary to consider that future law enforcement officers have personal resources of integration of scientific knowledge which are caused by inclinations, level of education and the acquired personal experience of educational and professional activity. Therefore, the great role is given to the identification of personal meaning and emotional satisfaction from educational and professional activities.

Real opportunities for development of creative abilities of future law enforcement officers are provided by research activity which acts as the integration factor of professional training. Research activity, as the holistic creative act, requires higher education applicants to understand interdisciplinary problems at different levels: methodological, theoretical, and applied.

Therefore, the didactically justified application of the integrative approach provides the high level of professional training of the future policeman, legal culture and his professional thinking.

\section{References:}

1. Дейк Т.А. Ван Язик. Познанние. Комуникация. М., 1989. 36 с.

2. Вишневський Л. Система цінностей у філософії англійських просвітителів // Шлях освіти, 2001. №2. С. 3-5.

3. Кремень В.Г. Освіта і наука України: шляхи модернізації (Факти, роздуми, перспективи). Київ: Грамота, 2003. 215 с.

4. Литературная энциклопедия терминов и понятий/ Гл.ред. и сост. A.Н. Николюкин. М.: НПК «Интервакс», 2001. 751с.

5. Навчальний план підготовки патрульних інспекторів департаменту патрульної поліції Міністерства внутрішніх справ України. Київ. 2018.

6. Нагаєв В.М. Методика викладання у вищій школі: Навч. посіб. Київ: Центр учбової літератури, 2007. 232 с.

Received to editorial office 24.11.2019 [in Rus.]

1. Deik, T.A and Yazyk, V. (1989) Poznanie. Komuniicatsia [Known. Communication] : M. 36 s.

2. Vishnevskyi, L. (2001) Systema tsinnostei u philosophii angliiskyh prosvetityliv [System of values in the philosophy of English educators ] : Path of education, № 2. s. 3-5. [in Rus.]

3. Kremen, V.H. (2003). Osvita I nauka Ukrainy: shlyahy modernizatsii (Facty, rozdumy, perspectyvy) [Education and science of Ukraine: directions of modernization (facts, thoughts, perspectives)] : Kyiv: Hramota. 215 s. [in Ukr.]

4. Literaturnaya entsiklopediya terminov i ponyatiy [Literary Encyclopedia of Terms and Concepts] : Gl.red. i sost. A.N. Nikolyukin. M.: NPK «Intervaks», 2001, 751 s. [in Rus.]

5. Navchalnyi plan pidhotovky patrulnykh inspektoriv departamentu patrulnoi politsii Minister- 
stva vnutrishnikh sprav Ukrainy [Curriculum for training patrol inspectors of the patrol police department of the Ministry of Internal Affairs of Ukraine] : Kyiv. 2018.

6. Nahaiev V.M. Metodyka vykladannia u vyshchii shkoli [Methods of teaching in high school] : Navch. posib. Kyiv: Tsentr uchbovoi literatury, 2007. $232 \mathrm{~s}$.

\section{Summary}

The article analyses the process of integration of psychological and legal knowledge, interpenetration, consolidation, unification of knowledge, the gradual change of individual didactic elements, which are included in the large number of connections and relationships.

Keywords: law enforcement officer, linguistics, interdisciplinary relations, integration, psychology, speech competence, education.

UDC 316.454.52.34

DOI: $10.31733 / 2078-3566-2019-5-297-302$

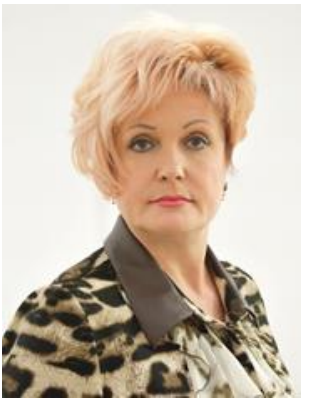

\section{Inna SHINKARENKO ${ }^{\circledR}$} Ph.D, Ass. Prof.

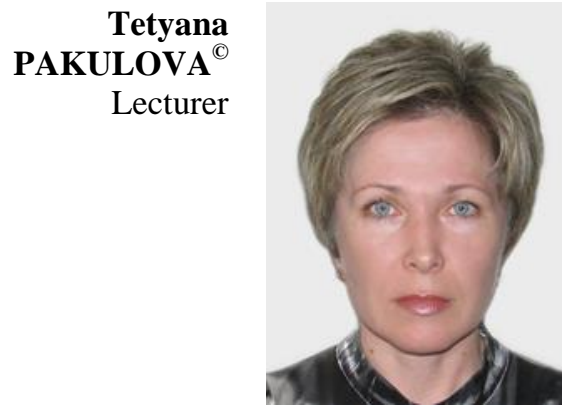

(Dnipropetrovsk State University of Internal Affairs)

\section{COMMUNICATIVE COMPETENCE AS A COMPONENT OF THE PROFESSIONAL SKILL OF THE INVESTIGATOR}

Інна Шинкаренко, Тетяна Пакулова. КОМУНІКАТИВНА КОМПЕТЕНЦІЯ ЯК СКЛАДОВА ПРОФЕСІЙНОЇ ПДГОТОВКИ СЛІДЧОГО. Об'єктивний аналіз діяльності працівників органів досудового розслідування дозволяє описати класи ситуацій професійного спілкування які, потребують від них відповідної професійною комунікативної компетентності.

У статті пропонується аналіз «ланцюга» діяльності працівника Національної поліції на прикладі діяльності слідчого з точки зору професійних комунікативних якостей, необхідних для фахового виконання його професійної діяльності. Виокремлено основні складники зазначених компетентностей та розглянуто специфіку комунікативних навичок працівників органів досудового розслідування 3 урахуванням вимог сучасності. Значну увагу приділено умінню свідомо керувати вербальними і невербальними проявами емоцій, вести конструктивний діалог як 3 правопорушниками, так і 3 неповнолітніми (малолітніми) та іншими категоріями громадян. Звертається увага на вдосконалення комунікативної компетентності працівників Національної поліції шляхом проведення соціально-психологічного тренінгу, що в свою чергу сприяє формуванню професійної майстерності фахівців.

Спілкування з правопорушником часто є маніпулятивним; суб'єкт - це об'єкт, де злочинець намагається діяти як активний суб'єкт, керуючи ситуацією. Навик слідчого часто своєчасно виявляти поведінку гри, зустрічну гру та ефективно взаємодіяти. У цьому складному процесі спілкування важливими професійними комунікативними якостями є: контроль за станом, який впливає на сприйняття ситуації та взаємодію з правопорушником; чутливість до особистості злочинця; здатність створити відповідні умови, за яких можна проводити подальшу роботу відповідно до умов особистості.

Виокремлено основні складники зазначених компетентностей та розглянуто специфіку комунікативних навичок працівників органів досудового розслідування 3 урахуванням вимог

\footnotetext{
(C) Shinkarenko I., 2019

ORCID iD: https://orcid.org/0000-0003-0040-2010

k_fp@dduvs.in.ua

(C) Pakulova T., 2019

ORCID iD: https://orcid.org/0000-0002-0251-684X

k-ump@dduvs.in.ua
} 